\title{
ITE's Polymer Activator Effect on Lead-acid Batteries
}

\author{
John C. Nardi ${ }^{1}$, Go Kawabe ${ }^{2}$, and Akiya Kozawa ${ }^{3}$ \\ ${ }^{1}$ ITE Yeager-Kozawa Battery Research Institute, editing@roadrunner.com \\ ${ }^{2}$ ITE Yeager-Kozawa Battery Research Institute, go.kawabe@hakoseki.jp \\ ${ }^{3}$ ITE Yeager-Kozawa Battery Research Institute, akiya-kozawa@mwb.biglobe.ne.jp
}

\begin{abstract}
The ITE organic polymer activators for extending the life of lead-acid batteries were first developed by a Japanese group in 1997 led by Dr. Akiya Kozawa. The initial activator was a composite mixture of carbon and polyvinyl alcohol. A US Patent (5,958,623) was issued on September 28, 1999 for this new lead-acid battery activator. Later research found that the organic polymer alone was very effective which started a wide search for other such organic additives. The most effective one to date is an acrylic polymer with a high molecular weight. This paper summarizes the current results involving this acrylic polymer.
\end{abstract}

\section{Keywords}

polymer activator, lead acid battery, hydrogen over voltage, specific gravity, cyclic voltammetry

\section{EFFECTIVE USES OF ORGANIC POLYMER ACTIVATOR}

(1) Extends the SLI (starting, lighting, ignition) leadacid battery life from current 3-4 years to more than 8-10 years.

(2) Regeneration of deteriorated (replaced) batteries from cars, trucks, buses, etc., is possible.

(3) Various deep cycle batteries for use in forklifts, golf carts, wheelchairs, etc.

(4) Reduction of the battery plate size by 25 to $35 \%$ for new lead-acid batteries.

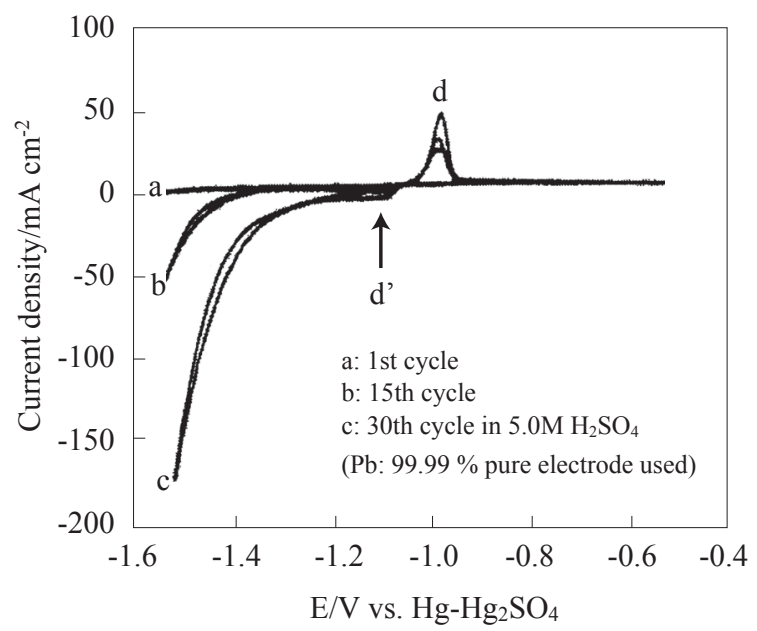

Fig. 1 Cyclic voltammogram between $-1.55 \mathrm{~V}$ and $-0.5 \mathrm{~V}$ vs. $\mathrm{Hg} / \mathrm{Hg}_{2} \mathrm{SO}_{4}$ without organic polymer in the acid solution

\section{BASIC STUDY (CYCLIC VOLTAMMETRY) OF METALLIC LEAD ELECTRODE}

A metallic lead electrode was measured by cyclic voltammetry up to 30 cycles. Figure 1 shows the results without adding the organic polymer activator to the electrolyte: a-first cycle, b-15th cycle, and c-30th cycle.

The lead electrode is oxidized to $\mathrm{PbSO}_{4}$ at the d voltage in Figure 1 and the surface $\mathrm{PbSO}_{4}$ is reduced to metallic lead at the d' voltage in Figure 1. With the increasing cycle number from 1 to 30 , increasing hydrogen evolution takes place as observed from cycles $a$ to $b$ to $c$. This indicates that the lead surface changes the hydrogen evolution overvoltage. It also shows that

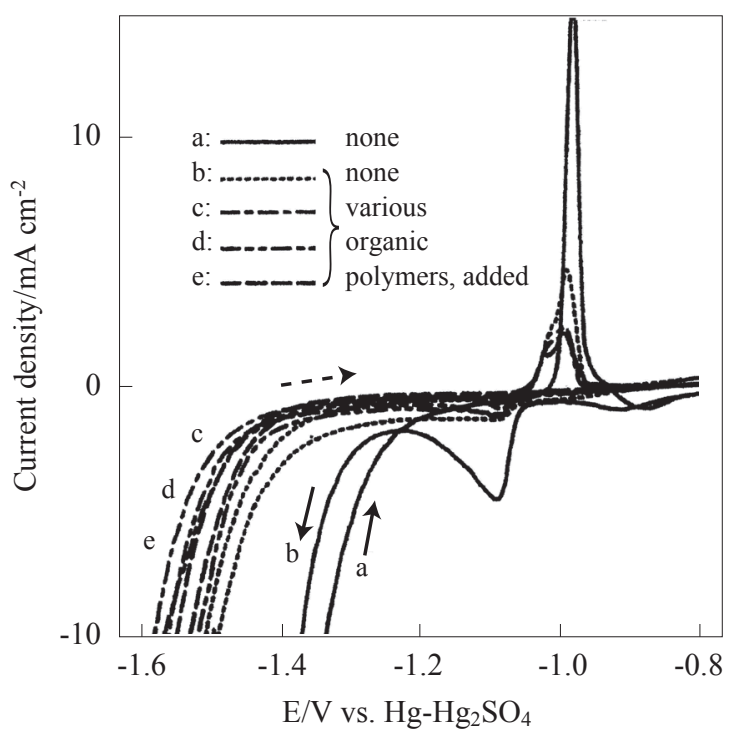

Fig. 2 Cyclic voltammogram with organic polymer $(0.1 \%)$ : Curve a: no polymer at 10 th cycle; b, c, d, e: addition of various polymers (PVA, etc.) 
when the lead surface is repeatedly charged and discharged, the hydrogen overvoltage increases. Figure 2 shows that curves $b, c, d$ and e shift to a more negative voltage indicating that the polymer reduces the hydrogen evolution from the negative electrode. Since the lead electrode has the following main reaction and side reaction.

(1) Main reaction:

$\mathrm{PbSO}_{4} \rightarrow \mathrm{Pb}^{2+}+\mathrm{SO}_{4}^{2-}+2 \mathrm{e}^{-} \rightarrow \mathrm{PbSO}_{4}$ (charge reaction)

(2) Side reaction:

$\mathrm{H}^{+}+\mathrm{e}^{-} \rightarrow \mathrm{H}_{2} \uparrow$ (hydrogen gas production)

We concluded based on the cyclic voltammetry results (Figures 1 and 2) that the organic polymers (polyvinyl alcohol, etc.) reduce the side reaction and the charge reaction is improved.

\section{RECOVERY OF 3-YEAR OLD TRUCK BAT- TERIES}

When truck batteries become old, the specific gravity of the electrolyte decreases and the charge becomes incomplete, because the hydrogen overvoltage decreases, i.e., the hydrogen gas evolution increases. A PVA (5\% polyvinyl polymer solution) was added at $120 \mathrm{cc}(20 \mathrm{cc} / \mathrm{cell}), 180 \mathrm{cc}$ (30 cc/cell) and $240 \mathrm{cc}$ (40 cc/cell) to 3 -year old truck lead-acid batteries. We observed that the specific gravities of all the batteries increased indicating the recovery of the battery's deterioration.

As seen for Battery 5 in Table 1, the specific gravity was initially an acceptable value (1.25-1.26). The specific gravity increase was not high since the accumula-

Table 1 Change in specific gravity values of 3-year old lead-acid batteries

Battery 1: $155 \mathrm{AH}$, one of two $12 \mathrm{~V}$ batteries; 10-ton truck with a total addition of $240 \mathrm{cc}$ additive

\begin{tabular}{|l|c|c|c|c|c|c|}
\hline & Cell 1 & Cell 2 & Cell 3 & Cell 4 & Cell 5 & Cell 6 \\
\hline $\begin{array}{l}\text { Before addition } \\
\text { February 21, 2002 }\end{array}$ & 1.12 & 1.13 & 1.14 & 1.14 & 1.14 & 1.14 \\
\hline $\begin{array}{l}3 \text { months after addition } \\
\text { June 2, 2002 }\end{array}$ & 1.27 & 1.28 & 1.28 & 1.28 & 1.28 & 1.27 \\
\hline $\begin{array}{l}5 \text { months after addition } \\
\text { Sept. 1, 2002 }\end{array}$ & 1.24 & 1.20 & 1.21 & 1.21 & 1.24 & 1.25 \\
\hline
\end{tabular}

Battery 2: $145 \mathrm{AH}$, one of two $12 \mathrm{~V}$ batteries; 10-ton truck with a total addition of $180 \mathrm{cc}$ additive

\begin{tabular}{|l|c|c|c|c|c|c|}
\hline & Cell 1 & Cell 2 & Cell 3 & Cell 4 & Cell 5 & Cell 6 \\
\hline $\begin{array}{l}\text { Before addition } \\
\text { June 2, 2002 }\end{array}$ & 1.21 & 1.21 & 1.20 & 1.18 & 1.18 & 1.20 \\
\hline $\begin{array}{l}1.5 \text { months after addition } \\
\text { July 21, 2002 }\end{array}$ & 1.26 & 1.25 & 1.25 & 1.26 & 1.26 & 1.25 \\
\hline $\begin{array}{l}3 \text { months after addition } \\
\text { Sept. 1, 2002 }\end{array}$ & 1.25 & 1.25 & 1.27 & 1.27 & 1.25 & 1.25 \\
\hline
\end{tabular}

Battery 3: $80 \mathrm{AH}$, one of two $12 \mathrm{~V}$ batteries; 4-ton truck with a total addition of $120 \mathrm{cc}$ additive

\begin{tabular}{|l|c|c|c|c|c|c|}
\hline & Cell 1 & Cell 2 & Cell 3 & Cell 4 & Cell 5 & Cell 6 \\
\hline $\begin{array}{l}\text { Before addition } \\
\text { June 9, 2002 }\end{array}$ & 1.18 & 1.18 & 1.19 & 1.20 & 1.20 & 1.19 \\
\hline $\begin{array}{l}3 \text { months after addition } \\
\text { Sept. 1, 2002 }\end{array}$ & 1.20 & 1.22 & 1.25 & 1.21 & 1.24 & 1.25 \\
\hline
\end{tabular}

Battery 4: $145 \mathrm{AH} 12 \mathrm{~V}$ batteries with a total addition of $180 \mathrm{cc}$ additive

\begin{tabular}{|l|c|c|c|c|c|c|}
\hline & Cell 1 & Cell 2 & Cell 3 & Cell 4 & Cell 5 & Cell 6 \\
\hline $\begin{array}{l}\text { Before addition } \\
\text { July 26, 2002 }\end{array}$ & 1.25 & 1.27 & 1.26 & 1.26 & 1.26 & 1.26 \\
\hline $\begin{array}{l}\text { 1 month after addition } \\
\text { August } 1,2002\end{array}$ & 1.28 & 1.30 & 1.25 & 1.25 & 1.27 & 1.28 \\
\hline
\end{tabular}


tion of uncharged $\mathrm{PbSO}_{4}$ was low.

\section{TESTING OF NEW LEAD-ACID BATTERIES}

When we add ITE's polymer activator to a new leadacid battery for testing and compare it to a battery with no added activator, the effect is not very different unless we significantly cycle the battery. This is because the new battery does not have a significant accumulation of $\mathrm{PbSO}_{4}$, i.e., sulfation.

Figure 3 shows the effect of the ITE activator testing. The activator's beneficial effect only appears during the later number of cycles. The effect is not initially observed.

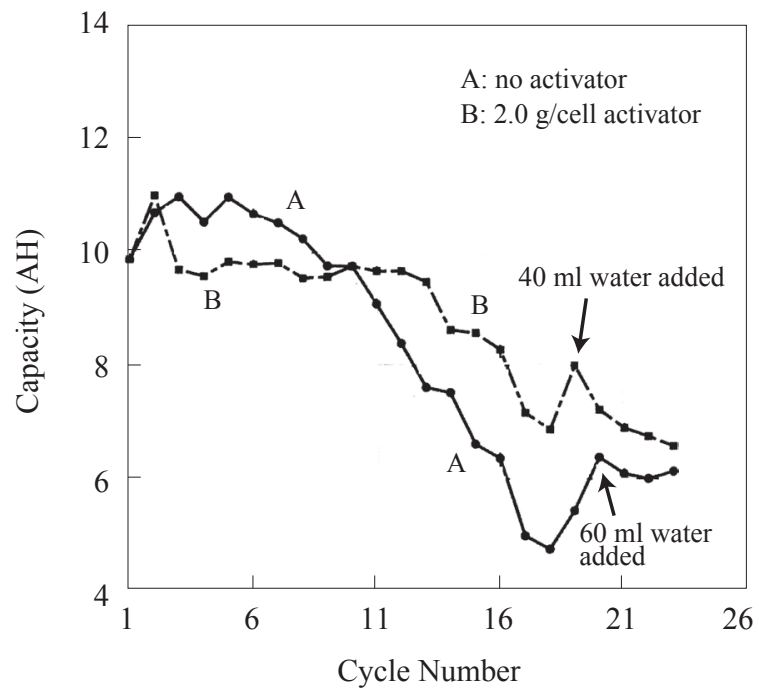

Fig. 3 Effect of ITE activator on 3-yr. guarantee battery (Panasonic)

\section{CONCLUSION}

In this paper, we discussed the effects of adding ITE's organic polymer additive on lead-acid truck batteries, since such batteries that are used in cars, trucks, buses, and taxis represent $60 \%$ of the lead-acid battery use. We have continued the truck battery testing for more than 10 years along with adding our activator only once per year. During this activator testing of 200 trucks owned by the Sanwa Unsho Truck Co. (Tokyo, Japan), no battery replacement took place during the entire test period. Based on these results, we plan to recommend the use of our activator test to companies all over the world. Based on 2010 lead-acid battery production figures of \$US36.2 billion, If successful, we will be able to contribute $60 \%$ of this value or approximately \$US20 billion to the world's environment by reducing the number of waste lead-acid batteries.

(Received October 2, 2012; accepted November 8, 2012) 